\title{
Household Food Insecurity, Dietary Diversity, and Stunting in Sub-Saharan Africa: A Systematic Review
}

\author{
Goudja Gassara and Jihua Chen *(i) \\ Department of Nutrition Science and Food Hygiene, Xiangya School of Public Health, Central South University, \\ Changsha 410008, China; goudjag@yahoo.fr \\ * Correspondence: chenjh@csu.edu.cn; Tel.: +86-0731-84135464
}

Citation: Gassara, G.; Chen, J.

Household Food Insecurity, Dietary Diversity, and Stunting in Sub-Saharan Africa: A Systematic Review. Nutrients 2021, 13, 4401. https://doi.org/10.3390/nu13124401

Academic Editor: Leonardo Palombi

Received: 28 October 2021

Accepted: 7 December 2021

Published: 9 December 2021

Publisher's Note: MDPI stays neutral with regard to jurisdictional claims in published maps and institutional affiliations.

Copyright: (c) 2021 by the authors. Licensee MDPI, Basel, Switzerland. This article is an open access article distributed under the terms and conditions of the Creative Commons Attribution (CC BY) license (https:/ / creativecommons.org/licenses/by/ $4.0 /)$.

\begin{abstract}
Background: The significant public health problem in Sub-Saharan Africa of household food insecurity is an underlying cause of malnutrition in Sub-Saharan Africa. This study aims to systematically study the association between household food insecurity, dietary diversity, and stunting. Methods: This review was carried out based on the recommendations of PRISMA (2015). We searched the literature in six bibliographic databases: PubMed, EMBASE, Science Direct, Web of Science, Google Scholar, and Scopus. The research was based on studies conducted in Sub-Saharan Africa about household food insecurity, dietary diversity, and stunting and was published between 2009 and 2020. Results: Out of 2398 original articles identified, only 21 articles met the specific requirements of this review. Two-thirds of the articles selected showed that stunting was linked to household food insecurity and dietary diversity. Conclusions: This study found that household food insecurity and dietary diversity are significantly associated with stunting in Sub-Saharan Africa. This review recommends that in order to yield a sustainable fight against childhood malnutrition in Sub-Saharan Africa, reliable guidelines and strategies are needed to address these factors related to malnutrition.
\end{abstract}

Keywords: dietary diversity; food insecurity; malnutrition; public health; stunting; Sub-Saharan Africa; systematic review; undernutrition

\section{Introduction}

Household food insecurity (HFI) is defined as the lack of physical, social, and economic access to sufficient, safe, and nutritious food to meet the needs and food preferences for an active and healthy life [1]. As the matter stands, and in developing countries, household food insecurity frequently manifests itself in the form of poorly diversified and micronutrient-deficient diets. Currently, HFI is associated with poor dietary diversity, poverty, and malnutrition, putting children's development at risk [2].

Food and nutritional insecurity are observed in two situations: insufficient food (hunger and malnutrition) and in cases of diseases resulting from inadequate nutrition (excess weight and specific needs). When these situations arise, it is up to the health sector to provide adequate treatment, rehabilitation, and adequate prevention to avoid the occurrence of other complications [3-5].

Despite favorable global economic growth, food insecurity and malnutrition continue to cause suffering to many of the world's population, particularly in Africa [6,7].

Household food insecurity, racial disparities, poverty, neglect, and family stress are seen as risk factors for early childhood development (ECD) [8]. A few studies have shown the association between household food insecurity (HFI) and poor early childhood development (ECD) [9-11]. One study showed that HFI was associated with developmental risk and adverse effects on function, academic performance, and social skills development in preschool and school-aged children in the United States (USA) [9]. In the USA, another study described HFI as associated with reduced performance, especially in academic, social, and psycho-emotional fields, from infancy through adolescence [10]. 
Achieving food security remains an important challenge in Sub-Saharan Africa. There is a growing gap between consumption, nutrition, and food availability at regional, household, and individual levels. Almost half of the population of this region lives below the poverty line and depends on rain-fed agriculture, animal husbandry, and fishing for their survival. Thus, to ensure its food security, Africa must considerably increase its agricultural production and productivity. This assertion is confirmed by a study which shows that despite the favorable developments in food security throughout the world, the problem remains very worrying in SSA, where 180 million people were undernourished from 1995-1997, that is to say, a third of population [12].

In Sub-Saharan Africa, food insecurity is due to conflict, climate change, and economic problems. Overall, progress in the fight against malnutrition remains insufficient in Africa. Three quarters of Africans cannot afford a healthy diet according to the Food and Agriculture Organization (FAO). Thus, more than half cannot afford an adequate supply of nutrients [13].

Defined as the number of different food groups consumed during a given period by an individual or household, dietary diversity in many situations is an important indicator of the nutritional status $[14,15]$. Several studies have shown that low nutritional variety is often associated with growth retardation in children [16].

During the critical phase of a child's development, i.e., from conception until the first 24 to 59 months after birth, stunting can lead to delayed cognitive and physical development that is difficult to reverse [17-19]. Therefore, in the short and long term, malnutrition has adverse effects on children's health and negatively affects the economic productivity of nations [20]. In Sub-Saharan Africa, most children under five suffer from stunting (39\%) [21].

No previous systematic review analyzed the relationship between household food insecurity and stunting and the relationship between dietary diversity and stunting in children under 5 in Sub-Saharan Africa. This study aimed to examine the relationship between these different factors, thus allowing the establishment of guidelines and practical interventions to improve the population's standard of living and thus reduce the prevalence of malnutrition in the region and sub-regions.

\section{Materials and Methods}

\subsection{Household Food Insecurity Indicator}

For this systematic review, the food security indicator used is the Household Food Insecurity Access Scale (HFIAS). The HFIAS scale consists of nine occurrence questions and nine frequency of occurrence questions.

\subsection{Anthropometric Indicator}

The anthropometric indicator retained for this systematic review is stunting. Nutritional indices in the articles were calculated using the WHO Anthro 3.1.0. The results were classified according to the thresholds of the World Organization Health 2006 [22]. Children with HAZ score below -2SD (standard deviation) were stunted. Children with HAZ scores greater than or equal to -2SD were considered normal.

\subsection{Food Diversity Indicators}

For this systematic review, the indicators used are three in number: the $24 \mathrm{~h}$ reminder, the 7-day reminder, and the standard $48 \mathrm{~h}$ reminder technique [23]. The reference for the dietary diversity period may vary, but most often corresponds to the day ( $24 \mathrm{~h}$ reminder) or the previous week (7-day reminder) [24,25].

$\sqrt{ } \quad$ For $24 \mathrm{~h}$ reminder, the household dietary diversity score (HDDS) equals the total number of different food groups consumed in the last $24 \mathrm{~h}$ by a household member at home, including foods prepared at home but eaten outside, such as a lunch bag [26,27]. 
$\sqrt{ }$ Concerning the 7-day reminder, this corresponds to the number of food groups consumed by a member of the household member during the last seven days from the total of 13 food groups.

$\sqrt{ } \quad$ Finally, the $48 \mathrm{~h}$ reminder corresponds to all food and drinks consumed by household members day and night during the previous $48 \mathrm{~h}$ at different times of meals [23].

\subsection{Research Strategy}

This systematic review of the literature was carried out in pairs according to the PRISMA recommendations (Preferred Reporting Items for Systematic reviews and MetaAnalyses) of 2015 [28]. The search was carried out based on a list of keywords. Subheadings of keywords were to exhaustively search for articles from six bibliographic databases: PubMed, EMBASE, Science Direct, Web of Science, Google Scholar, and Scopus. The research focused on studies conducted in all countries (48) of Sub-Saharan Africa and published between 2009 and 2020. We have searched for additional relevant studies manually using the retrieved article references. The following combined keywords were used for the search:

(Household food insecurity* OR HFI* OR dietary diversity* OR DD* OR stunting* OR stunt*).

\subsection{Inclusion and Exclusion Criteria}

The inclusion criteria were: (1) original articles related to the topic of interest of this study; (2) studies evaluating the association between household food insecurity and stunting as well as dietary diversity and stunting in children under five; (3) studies carried out in Sub-Saharan Africa; (4) studies published between 2009 and 2020; (5) cross-sectional studies (books, qualitative studies, policy briefs, case studies, and theses were excluded); (6) studies published in a peer-reviewed journal (reviews, non-peer-reviewed research, and comments were excluded); (7) studies published in English.

\subsection{Data Extraction}

The use of the EndNote library allowed us to remove all duplicate articles. From the title and the summary, the first reading phase allowed us to remove some selected articles. Then after a full reading of the articles, we selected studies that met the inclusion/exclusion criteria. We independently reviewed the retained articles and rejected all those that met the exclusion criteria. The following information was extracted from the articles selected: author(s), year, country, number of children, age of children, number of households, sample, location, study purpose, method of HFI evaluation, method of DD evaluation, stunting, and finally the results (HFI/Stunting, DD/Stunting, and Prevalence Stunting) (Table 1). The studies were also grouped by country into SSA sub-regions (West Africa, East Africa, Southern Africa, and Central Africa) based on the United Nations (UN) scheme classification and by year of publication.

\subsection{Quality Assessment}

The Joanna Briggs Institute (JBI) checklist for Cross-Sectional Analytical Studies [29] was applied to assess the quality of the articles reviewed. The assessment of the quality of the selected studies is presented in the Supplementary Table S1. The selected studies were homogeneous, and all analyses were of high quality according to the JBI-MAStARI. 
Table 1. Summary of selected articles.

\begin{tabular}{|c|c|c|c|c|c|c|}
\hline \multicolumn{7}{|c|}{ West Africa } \\
\hline $\begin{array}{l}\text { Author } \\
\text { [Ref.], } \\
\text { Year, } \\
\text { Country }\end{array}$ & $\begin{array}{l}\text { No. of Children (N0), } \\
\text { Age, } \\
\text { No. of Households (N1) }\end{array}$ & Sample/Location & Study Purpose & $\begin{array}{c}\text { Methods of HFI, DD } \\
\text { Evaluation and } \\
\text { Stunting }\end{array}$ & HFI and Stunting & DDS and Stunting \\
\hline $\begin{array}{l}\text { Hatley, A. et al. } \\
\text { [30] } \\
2000 \\
\text { Mali }\end{array}$ & $\begin{array}{l}\text { N0 }=526 \text { Urban and } \\
1789 \text { Rural } \\
6-59 \text { months } \\
N 1=329 \text { Urban and } \\
488 \text { Rural }\end{array}$ & $\begin{array}{c}\text { The study was } \\
\text { conducted in Koutia } \\
\text { County, Sikasso region. } \\
\text { The sample consists of } \\
329 \text { urban households } \\
\text { and } 488 \text { rural } \\
\text { households with } \\
526 \text { urban children and } \\
1789 \text { rural children aged } \\
6 \text { to } 59 \text { months. }\end{array}$ & $\begin{array}{l}\text { To analyze the } \\
\text { associations between the } \\
\text { food variety score (FVS), } \\
\text { the dietary diversity } \\
\text { score (DDS), and } \\
\text { children's nutritional } \\
\text { status. }\end{array}$ & $\begin{array}{c}\text {-Socioeconomic and } \\
\text { demographic } \\
\text { questionnaires } \\
-24 \mathrm{~h} \text { reminder } \\
\text {-HAZ }\end{array}$ & & $\begin{array}{l}\text { Doubled risk of stunting } \\
\text { in urban children with } \\
\text { low dietary diversity } \\
\text { score. }\end{array}$ \\
\hline $\begin{array}{c}\text { Mahama, S. et al. } \\
{[31]} \\
2013 \\
\text { Ghana }\end{array}$ & $\begin{array}{c}N_{0}=337 \\
6-36 \text { months } \\
N_{1}=337\end{array}$ & $\begin{array}{l}\text { The study was } \\
\text { conducted in the } \\
\text { metropolis of Tamale. } \\
\text { A sample of } \\
337 \text { mother/child pairs } \\
\text { made up the study. }\end{array}$ & $\begin{array}{l}\text { Assess the extent of } \\
\text { household food } \\
\text { insecurity and its } \\
\text { consequences on the } \\
\text { nutritional status of } \\
\text { children aged } 6 \text { to } \\
36 \text { months and their } \\
\text { mothers. }\end{array}$ & $\begin{array}{l}\text {-Socioeconomic and } \\
\text { demographic } \\
\text { questionnaires } \\
\text {-HFIAS } \\
\text {-7-day reminder } \\
\text {-HAZ }\end{array}$ & $\begin{array}{l}\text { The relationship } \\
\text { between food insecurity } \\
\text { and stunting was } \\
\text { stronger in children aged } \\
\text { at least } 23 \text { months } \\
(p=0.019) . \\
29.8 \% \text { stunting. } \\
54 \% \text { household food } \\
\text { insecurity. }\end{array}$ & \\
\hline $\begin{array}{c}\text { Ali, S. et al. } \\
\text { [32] } \\
2018 \\
\text { Burkina Faso }\end{array}$ & $\begin{array}{c}N_{0}=251 \\
6-59 \text { months } \\
N_{1}=251\end{array}$ & $\begin{array}{l}\text { The study was carried } \\
\text { out in the sub-Sahelian } \\
\text { villages of Kamadena } \\
\text { and Dara. A total of } \\
251 \text { children were } \\
\text { included in the study. }\end{array}$ & $\begin{array}{l}\text { Evaluate dietary } \\
\text { diversity patterns in } \\
\text { children under } 5 \text { years of } \\
\text { age during the lean } \\
\text { season (July) and assess } \\
\text { the association between } \\
\text { dietary diversity and } \\
\text { nutritional status. }\end{array}$ & $\begin{array}{l}\text {-Sociodemographic } \\
\text { questionnaires } \\
\text {-7-day reminder } \\
\text {-HAZ }\end{array}$ & & $\begin{array}{l}\text { The association between } \\
\text { dietary diversity and } \\
\text { linear growth was } \\
\text { stronger in children } \\
\text { younger than } 36 \text { months. } \\
\text { Stunting } 27.7 \% \text { in } \\
\text { Kamadena against } 13.1 \% \\
\text { in Dara. }\end{array}$ \\
\hline
\end{tabular}


Table 1. Cont.

\begin{tabular}{|c|c|c|c|c|c|c|}
\hline \multicolumn{7}{|c|}{ Central Africa } \\
\hline $\begin{array}{l}\text { Author } \\
\text { [Ref.], } \\
\text { Year, } \\
\text { Country }\end{array}$ & $\begin{array}{l}\text { No. of Children (N0), } \\
\text { Age, } \\
\text { No. of Households (N1) }\end{array}$ & Sample/Location & Study Purpose & $\begin{array}{c}\text { Methods of HFI, DD } \\
\text { Evaluation and } \\
\text { Stunting }\end{array}$ & HFI and Stunting & DDS and Stunting \\
\hline $\begin{array}{c}\text { B.N. Ekesa et al. } \\
{[33]} \\
2011 \\
\text { DRC * } \\
\text { Burundi } \\
\text { * DRC = Democratic } \\
\text { Republic of Congo }\end{array}$ & $\begin{array}{c}N_{0}=281 \\
24-59 \text { months } \\
N_{1}=281\end{array}$ & $\begin{array}{l}\text { The study was carried } \\
\text { out in the Gitega area } \\
\text { and the Butembo area. } \\
\text { The sample includes } \\
281 \text { households, } \\
\text { including } 138 \text { in } \\
\text { Butembo and } 143 \\
\text { in Gitega. }\end{array}$ & $\begin{array}{l}\text { Assess the dietary } \\
\text { diversity and nutritional } \\
\text { status of preschool } \\
\text { children. }\end{array}$ & $\begin{array}{c}\text {-Sociodemographic } \\
\text { questionnaires } \\
\text {-24 h reminder } \\
\text {-HAZ }\end{array}$ & & $\begin{array}{l}\text { DRC: } 78.86 \% \text { stunting, no } \\
\text { relationship between } \\
\text { dietary diversity and } \\
\text { stunting }(p>0.05) . \\
\text { Burundi: } 63.57 \% \text { stunting. } \\
\text { In Burundi, the } \\
\text { relationship between } \\
\text { dietary diversity and } \\
\text { weight for age was not } \\
\text { significant }\left(\mathrm{r}^{2}=0.051\right) .\end{array}$ \\
\hline \multicolumn{7}{|c|}{ East Africa } \\
\hline $\begin{array}{l}\text { Author } \\
\text { [Ref.], } \\
\text { Year, } \\
\text { Country }\end{array}$ & $\begin{array}{l}\text { No. of Children (N0), } \\
\text { Age, } \\
\text { No. of Households (N1) }\end{array}$ & Sample/Location & Study Purpose & $\begin{array}{l}\text { Methods of HFI, DD } \\
\text { Evaluation and } \\
\text { Stunting }\end{array}$ & HFI and Stunting & DDS and Stunting \\
\hline $\begin{array}{c}\text { Ali, D. et al. } \\
\text { [34] } \\
2013 \\
\text { Ethiopia }\end{array}$ & $\begin{array}{c}N_{0}=2356 \\
6-59 \text { months } \\
N_{1}=2992\end{array}$ & $\begin{array}{l}\text { The baseline survey in } \\
\text { Ethiopia included } \\
2992 \text { households and } \\
2356 \text { children aged } \\
\text { 6-59 months; surveys } \\
\text { conducted in } \\
75 \text { enumeration areas in } \\
\text { the } 2 \text { regions. }\end{array}$ & $\begin{array}{c}\text { Examine the association } \\
\text { between HFI and child } \\
\text { undernutrition in } \\
\text { Bangladesh, Ethiopia } \\
\text { and Vietnam using } \\
\text { HFIAS. }\end{array}$ & $\begin{array}{c}\text {-Sociodemographic } \\
\text { questionnaires } \\
\text {-HFIAS } \\
\text {-24 h reminder } \\
\text {-HAZ }\end{array}$ & & $\begin{array}{l}50.7 \% \text { stunting in children. } \\
\text { HFI was significantly } \\
\text { associated with stunting. }\end{array}$ \\
\hline $\begin{array}{c}\text { Zipporah, N. et al. } \\
{[35]} \\
2014 \\
\text { Kenya }\end{array}$ & $\begin{array}{c}N_{0}=277 \\
6-36 \text { months } \\
N_{1}=277\end{array}$ & $\begin{array}{c}\text { A sample of } \\
277 \text { women }- \text { child } \\
\text { couples was selected. } \\
\text { The study was } \\
\text { conducted in two } \\
\text { counties (Machakos and } \\
\text { Makueni). }\end{array}$ & $\begin{array}{l}\text { Contribute to improving } \\
\text { food security for women } \\
\text { and men in communities } \\
\text { prone to hunger. }\end{array}$ & $\begin{array}{c}\text {-Sociodemographic } \\
\text { questionnaires } \\
-24 \text { h reminder } \\
\text {-HAZ }\end{array}$ & & $\begin{array}{c}\text { There is a significant } \\
\text { association }(p=0.023) \\
\text { between severe food } \\
\text { insecurity and the } \\
\text { nutritional status of } \\
\text { children. } \\
\text { 33.8\% stunting. }\end{array}$ \\
\hline
\end{tabular}


Table 1. Cont.

\begin{tabular}{|c|c|c|c|c|c|c|}
\hline \multicolumn{7}{|c|}{ East Africa } \\
\hline $\begin{array}{l}\text { Author } \\
\text { [Ref.], } \\
\text { Year, } \\
\text { Country }\end{array}$ & $\begin{array}{l}\text { No. of Children (N0), } \\
\text { Age, } \\
\text { No. of Households (N1) }\end{array}$ & Sample/Location & Study Purpose & $\begin{array}{c}\text { Methods of HFI, DD } \\
\text { Evaluation and } \\
\text { Stunting }\end{array}$ & HFI and Stunting & DDS and Stunting \\
\hline $\begin{array}{c}\text { Motbainor, A. et al. } \\
\text { [36] } \\
2015 \\
\text { Ethiopia }\end{array}$ & $\begin{array}{c}N_{0}=3964 \\
0-59 \text { months } \\
N_{1}=4110\end{array}$ & $\begin{array}{l}\text { The sample is made up } \\
\text { of } 4110 \text { households } \\
\text { chosen at random. } \\
\text { The study was carried } \\
\text { out in the Gojjam East } \\
\text { and West areas of the } \\
\text { Amhara region. }\end{array}$ & $\begin{array}{l}\text { Determine the level of } \\
\text { child malnutrition by } \\
\text { comparing the two } \\
\text { populations and assess } \\
\text { the association between } \\
\text { food insecurity and the } \\
\text { nutritional status of } \\
\text { children. }\end{array}$ & $\begin{array}{l}\text {-Sociodemographic } \\
\text { questionnaires } \\
\text {-HFIAS } \\
\text {-24 h reminder } \\
\text {-HAZ }\end{array}$ & $\begin{array}{c}\text { Food insecurity was } \\
\text { significantly associated } \\
\text { with wasting }(p<0.05) \text {. } \\
37.6 \% \text { stunting. }\end{array}$ & $\begin{array}{c}\text { Dietary diversity } \\
\text { associated considerably } \\
\text { with stunting }(p<0.05) .\end{array}$ \\
\hline $\begin{array}{c}\text { Mutisya, M. et al. } \\
{[37]} \\
2015 \\
\text { Kenya }\end{array}$ & $\begin{array}{c}N_{0}=6858 \\
6-23 \text { months } \\
N_{1}=6552\end{array}$ & $\begin{array}{l}\text { The sample is made up } \\
\text { of } 6858 \text { children and } \\
6552 \text { households. The } \\
\text { study was carried out in } \\
\text { two informal settlements } \\
\text { (Viwandani and } \\
\text { Korogocho) in the capital } \\
\text { Nairobi. }\end{array}$ & $\begin{array}{l}\text { To examine the effect of } \\
\text { household food security } \\
\text { status and its interaction } \\
\text { with household wealth } \\
\text { status on stunting in } \\
\text { children aged } 6 \text { to } \\
23 \text { months. }\end{array}$ & $\begin{array}{c}\text {-Socio-economic and } \\
\text { demographic } \\
\text { questionnaires } \\
\text {-HFIAS } \\
\text {-HAZ }\end{array}$ & $\begin{array}{l}\text { According to the three } \\
\text { Cox regression models, } \\
\text { this study shows that } \\
\text { household food security } \\
\text { is significantly } \\
\text { associated with stunting. } \\
49 \% \text { stunting. }\end{array}$ & \\
\hline $\begin{array}{c}\text { M'Kaibi, F.K. et al. } \\
\text { [38] } \\
2016 \\
\text { Kenya }\end{array}$ & $\begin{array}{c}N_{0}=500 \\
24-59 \text { months } \\
N_{1}=500\end{array}$ & $\begin{array}{l}\text { The study was } \\
\text { conducted in two rural } \\
\text { areas (Akithii and } \\
\text { Uringu). The sample is } \\
\text { composed of } \\
500 \text { respondents. }\end{array}$ & $\begin{array}{l}\text { To determine the role of } \\
\text { dietary diversity (DD), } \\
\text { household food security } \\
\text { (HFS), and agricultural } \\
\text { biodiversity (AB) on } \\
\text { stunting in children. }\end{array}$ & $\begin{array}{c}\text {-Sociodemographic } \\
\text { questionnaires } \\
\text {-HFIAS } \\
\text {-24 h reminder } \\
\text {-HAZ }\end{array}$ & $\begin{array}{l}\text { There is no significant } \\
\text { relationship between } \\
\text { household food security } \\
\text { and the nutritional status } \\
\text { of children. }\end{array}$ & $\begin{array}{l}\text { There is a significant } \\
\text { positive relationship in } \\
\text { this study between } \\
\text { stunting in children and } \\
\text { the dietary diversity of } \\
\text { the child in phase } 2 \text { of } \\
\text { the study. } \\
\text { The percentage stunting } \\
\text { for phase } 1 \text { was } 34.7 \% \text { in } \\
\text { Akithii and } 26.3 \% \text { in } \\
\text { Uringu. }\end{array}$ \\
\hline
\end{tabular}


Table 1. Cont.

\begin{tabular}{|c|c|c|c|c|c|c|}
\hline \multicolumn{7}{|c|}{ East Africa } \\
\hline $\begin{array}{l}\text { Author } \\
\text { [Ref.], } \\
\text { Year, } \\
\text { Country }\end{array}$ & $\begin{array}{c}\text { No. of Children (N0), } \\
\text { Age, } \\
\text { No. of Households (N1) }\end{array}$ & Sample/Location & Study Purpose & $\begin{array}{l}\text { Methods of HFI, DD } \\
\text { Evaluation and } \\
\text { Stunting }\end{array}$ & HFI and Stunting & DDS and Stunting \\
\hline $\begin{array}{c}\text { Abdurahman, A.A. et al. } \\
{[39]} \\
2016 \\
\text { Ethiopia }\end{array}$ & $\begin{array}{c}N_{0}=453 \\
24-59 \text { months } \\
N_{1}=453\end{array}$ & $\begin{array}{l}\text { The total sample is made } \\
\text { up of } 453 \text { households. } \\
\text { The study was carried } \\
\text { out in the Eastern } \\
\text { Haraghe area of } \\
\text { Haromaya district. }\end{array}$ & $\begin{array}{l}\text { This study aimed to examine } \\
\text { the association between } \\
\text { household food insecurity } \\
\text { and the nutritional status of } \\
\text { children aged } 24 \text { to } \\
59 \text { months. }\end{array}$ & $\begin{array}{c}\text {-Socio-economic and } \\
\text { demographic } \\
\text { questionnaires } \\
\text {-HFIAS } \\
\text {-HAZ }\end{array}$ & $\begin{array}{c}\text { Household food } \\
\text { insecurity was } \\
\text { significantly predictive } \\
\text { of being underweight } \\
(p=0.05) \text {. } \\
61.1 \% \text { stunting. }\end{array}$ & \\
\hline $\begin{array}{c}\text { Mulu, E. et al. } \\
{[40]} \\
2017 \\
\text { Ethiopia }\end{array}$ & $\begin{array}{c}N_{0}=555 \\
6-59 \text { months } \\
N_{1}=576\end{array}$ & $\begin{array}{l}\text { The sample is made up } \\
\text { of } 576 \text { households with } \\
\text { children under five. The } \\
\text { study was carried out in } \\
\text { the Sekela district. }\end{array}$ & $\begin{array}{l}\text { This study was conducted to } \\
\text { compare the nutritional } \\
\text { status of children in } \\
\text { food-secure and } \\
\text { food-insecure households. }\end{array}$ & $\begin{array}{c}\text {-Socio-economic and } \\
\text { demographic } \\
\text { questionnaires } \\
\text {-HFIAS } \\
\text {-HAZ }\end{array}$ & $\begin{array}{c}\text { Household food } \\
\text { insecurity was not } \\
\text { significantly associated } \\
\text { with stunting. } \\
36.9 \% \text { stunting. }\end{array}$ & \\
\hline $\begin{array}{c}\text { Betebo, B. et al. } \\
{[41]} \\
2017 \\
\text { Ethiopia }\end{array}$ & $\begin{array}{c}N_{0}=508 \\
6-59 \text { months } \\
N_{1}=508\end{array}$ & $\begin{array}{l}\text { The sample is made up } \\
\text { of } 508 \text { mother - child } \\
\text { couples aged } 6 \text { to } \\
59 \text { months. The study } \\
\text { was conducted in the } \\
\text { district of East } \\
\text { Badawacho. }\end{array}$ & $\begin{array}{l}\text { Assess household food } \\
\text { insecurity and its association } \\
\text { with the nutritional status of } \\
\text { children aged } 6 \text { to } \\
59 \text { months. }\end{array}$ & $\begin{array}{c}\text {-Socio-economic and } \\
\text { demographic } \\
\text { questionnaires } \\
\text {-HFIAS } \\
\text {-HAZ }\end{array}$ & $\begin{array}{c}\text { Household food } \\
\text { insecurity is significantly } \\
\text { associated with stunting. } \\
45.6 \% \text { stunting. }\end{array}$ & \\
\hline $\begin{array}{c}\text { Agho, K.E. et al. } \\
{[42]} \\
2018 \\
\text { Rwanda }\end{array}$ & $\begin{array}{c}N_{0}=2222 \\
6-59 \text { months } \\
N_{1}=660\end{array}$ & $\begin{array}{l}\text { The present analysis } \\
\text { included } 2222 \text { children } \\
\text { aged } 6 \text { to } 59 \text { months, } \\
\text { conducted in the } \\
\text { Gicumbi district. }\end{array}$ & $\begin{array}{l}\text { To examine the association } \\
\text { between household food } \\
\text { insecurity (HFI) and } \\
\text { stunting and severe stunting } \\
\text { in children aged } 6 \text { to } \\
59 \text { months. }\end{array}$ & $\begin{array}{c}\text {-Sociodemographic } \\
\text { questionnaires } \\
\text {-HFIAS } \\
\text {-HAZ }\end{array}$ & $\begin{array}{l}\text { HFI is significantly } \\
\text { associated with stunting. } \\
\text { Children aged } 24 \text { to } \\
59 \text { months }(p<0.001) \\
\text { were more likely to be } \\
\text { stunted than children } \\
\text { aged } 5 \text { to } 23 \text { months. }\end{array}$ & \\
\hline $\begin{array}{c}\text { Shilugu, L.L. et al. } \\
{[43]} \\
2019 \\
\text { Tanzania }\end{array}$ & $\begin{array}{c}N_{0}=358 \\
6-59 \text { months } \\
N_{1}=358\end{array}$ & $\begin{array}{l}\text { The sample is made up } \\
\text { of } 358 \text { tutors and } 358 \\
\text { children under } 5 \text { years } \\
\text { old. This cross-sectional } \\
\text { study was carried out in } \\
\text { the district of Bukombe. }\end{array}$ & $\begin{array}{l}\text { To examine the extent of } \\
\text { stunting among children } \\
\text { under } 5 \text { in peasant } \\
\text { households compared to } \\
\text { children from families } \\
\text { engaged in other economic } \\
\text { activities. }\end{array}$ & $\begin{array}{l}\text {-Sociodemographic } \\
\text { questionnaires } \\
\text {-24 h reminder } \\
\text {-HFIAS } \\
\text {-HAZ }\end{array}$ & $\begin{array}{l}\text { Food insecurity is } \\
\text { associated with stunting } \\
\text { in children, but the } \\
\text { association did not reach } \\
\text { a statistically significant } \\
\text { level ( } p=0.063) . \\
56.2 \% \text { stunting. }\end{array}$ & \\
\hline
\end{tabular}


Table 1. Cont.

\begin{tabular}{|c|c|c|c|c|c|c|}
\hline \multicolumn{7}{|c|}{ East Africa } \\
\hline $\begin{array}{l}\text { Author } \\
\text { [Ref.], } \\
\text { Year, } \\
\text { Country }\end{array}$ & $\begin{array}{c}\text { No. of Children (N0), } \\
\text { Age, } \\
\text { No. of Households (N1) }\end{array}$ & Sample/Location & Study Purpose & $\begin{array}{l}\text { Methods of HFI, DD } \\
\text { Evaluation and } \\
\text { Stunting }\end{array}$ & HFI and Stunting & DDS and Stunting \\
\hline $\begin{array}{c}\text { Khamis, A.G. et al. } \\
{[44]} \\
2019 \\
\text { Tanzania }\end{array}$ & $\begin{array}{c}N_{0}=2960 \\
6-23 \text { months } \\
N_{1}=13376\end{array}$ & $\begin{array}{l}\text { The sample consisted of } \\
13,376 \text { households, and } \\
\text { only children aged } 6 \text { to } \\
23 \text { months during the } \\
\text { study, matched with } \\
\text { their mothers, were } \\
\text { ultimately selected for } \\
\text { further analysis. }\end{array}$ & $\begin{array}{l}\text { Examine the role of } \\
\text { children's dietary } \\
\text { diversity on } \\
\text { undernutrition in } \\
\text { Tanzania using the large } \\
\text { dataset available } \\
\text { representing the country. }\end{array}$ & $\begin{array}{c}\text {-Sociodemographic } \\
\text { questionnaires } \\
\text {-24 h reminder } \\
\text {-HAZ }\end{array}$ & & $\begin{array}{l}\text { There is a significant } \\
\text { relationship between } \\
\text { dietary diversity and } \\
\text { stunting. } \\
31 \% \text { stunting. }\end{array}$ \\
\hline $\begin{array}{c}\text { Dinku, A.M. et al. } \\
{[45]} \\
2020 \\
\text { Ethiopia }\end{array}$ & $\begin{array}{c}N_{0}=512 \\
6-59 \text { months } \\
N_{1}=512\end{array}$ & $\begin{array}{l}\text { The sample size is } \\
512 \text { mother-child pairs. } \\
\text { The study was } \\
\text { conducted in the towns } \\
\text { of Dessie and } \\
\text { Combolcha. }\end{array}$ & $\begin{array}{l}\text { Explore the nutritional } \\
\text { status of children aged } 6 \\
\text { to } 59 \text { months and study } \\
\text { their potential } \\
\text { covariates. }\end{array}$ & $\begin{array}{c}\text {-Socio-economic and } \\
\text { demographic } \\
\text { questionnaires } \\
\text {-HFIAS } \\
\text {-24 h reminder } \\
\text {-HAZ }\end{array}$ & $\begin{array}{l}\text { Food insecurity was not } \\
\text { associated with any of } \\
\text { the anthropometric } \\
\text { indices. } \\
42.9 \% \text { stunting. }\end{array}$ & $\begin{array}{l}\text { Dietary diversity was } \\
\text { significantly associated } \\
\text { with stunting. }\end{array}$ \\
\hline $\begin{array}{c}\text { Berra, W.G. et al. } \\
{[46]} \\
2020 \\
\text { Ethiopia }\end{array}$ & $\begin{array}{c}N_{0}=525 \\
6-23 \text { months } \\
N_{1}=525\end{array}$ & $\begin{array}{l}\text { The sample for this } \\
\text { study is made up of } \\
525 \text { households. The } \\
\text { study was carried out in } \\
\text { the western areas of } \\
\text { Oromia. }\end{array}$ & $\begin{array}{l}\text { Determine the } \\
\text { associations between } \\
\text { household food } \\
\text { insecurity and child } \\
\text { undernutrition and } \\
\text { assess the prevalence of } \\
\text { stunting, underweight, } \\
\text { and wasting among the } \\
\text { targeted children. }\end{array}$ & $\begin{array}{c}\text {-Sociodemographic } \\
\text { questionnaires } \\
\text {-HFIAS } \\
\text {-HAZ }\end{array}$ & $\begin{array}{c}\text { Children living in } \\
\text { moderately } \\
\text { food-insecure } \\
\text { households were } \\
\text { significantly associated } \\
\text { with stunting. } \\
16.2 \% \text { stunting. }\end{array}$ & \\
\hline $\begin{array}{c}\text { Berhane, H.Y. et al. } \\
{[47]} \\
2020 \\
\text { Ethiopia }\end{array}$ & $\begin{array}{c}N_{0}=5822 \\
0-59 \text { months } \\
N_{1}=5467\end{array}$ & $\begin{array}{l}\text { The sample is made up } \\
\text { of } 5467 \text { households and } \\
5822 \text { children under five. } \\
\text { This study was } \\
\text { conducted on the } \\
\text { population of the city of } \\
\text { Addis Ababa. }\end{array}$ & $\begin{array}{l}\text { Describe urban } \\
\text { preschool children's diet } \\
\text { and nutritional status, } \\
\text { emphasizing } \\
\text { stratification and the } \\
\text { relative importance of } \\
\text { socio-economic factors. }\end{array}$ & $\begin{array}{c}\text {-Socio-economic and } \\
\text { demographic } \\
\text { questionnaires } \\
\text {-HFIAS } \\
\text {-24 h reminder } \\
\text {-HAZ }\end{array}$ & $\begin{array}{c}\text { Stunting was } \\
\text { significantly associated } \\
\text { with household food } \\
\text { insecurity. The risk of } \\
\text { stunting is } 1.4 \text { times } \\
\text { higher in children from } \\
\text { severe food-insecure } \\
\text { households. } \\
19.6 \% \text { stunting. }\end{array}$ & \\
\hline
\end{tabular}


Table 1. Cont.

\begin{tabular}{|c|c|c|c|c|c|c|}
\hline \multicolumn{7}{|c|}{ South Africa } \\
\hline $\begin{array}{l}\text { Author } \\
\text { [Ref.], } \\
\text { Year, } \\
\text { Country }\end{array}$ & $\begin{array}{l}\text { No. of Children (N0), } \\
\text { Age, } \\
\text { No. of Households (N1) }\end{array}$ & Sample/Location & Study Purpose & $\begin{array}{l}\text { Methods of HFI, DD } \\
\text { Evaluation and } \\
\text { Stunting }\end{array}$ & HFI and Stunting & DDS and Stunting \\
\hline $\begin{array}{l}\text { Faber, M. et al. } \\
\qquad[48] \\
2009 \\
\text { South Africa }\end{array}$ & $\begin{array}{c}N_{0}=167 \\
6-71 \text { months } \\
N_{1}=499\end{array}$ & $\begin{array}{l}\text { The sample includes } \\
499 \text { households. Study } \\
\text { was conducted in the } \\
\text { Grand Sekhukhune } \\
\text { district of Limpopo } \\
\text { province. }\end{array}$ & $\begin{array}{l}\text { Describe the relationship } \\
\text { between dietary } \\
\text { diversity and other } \\
\text { indicators of food } \\
\text { security. }\end{array}$ & $\begin{array}{c}\text {-Sociodemographic } \\
\text { questionnaires } \\
\text {-HFIAS } \\
-24 \text { h reminder } \\
\text {-HAZ }\end{array}$ & $\begin{array}{c}\text { An inverse correlation } \\
\text { between HFIAS and } \\
\text { dietary diversity } \\
(\mathrm{r}=0.450 ; p<0.01) \text { was } \\
\text { observed. } \\
34.7 \% \text { of the children } \\
\text { were stunted. }\end{array}$ & $\begin{array}{l}\text { Households with at least } \\
\text { one stunted child had a } \\
\text { lower dietary diversity. } \\
\text { Dietary diversity is a } \\
\text { promising indicator for } \\
\text { food security. }\end{array}$ \\
\hline $\begin{array}{c}\text { Chakona, G. et al. } \\
{[49]} \\
2017 \\
\text { South Africa }\end{array}$ & $\begin{array}{c}N_{0}=216 \\
24-59 \text { months } \\
N_{1}=554\end{array}$ & $\begin{array}{l}\text { The study was carried } \\
\text { out in three South } \\
\text { African cities (Richards } \\
\text { Bay, Dundee, and } \\
\text { Harrismith). The sample } \\
\text { is made up of } \\
554 \text { household women } \\
\text { and } 216 \text { children from } \\
2 \text { to } 5 \text { years old. }\end{array}$ & $\begin{array}{l}\text { Measure and explore the } \\
\text { links between household } \\
\text { food insecurity, dietary } \\
\text { diversity, and children's } \\
\text { nutritional status with } \\
\text { the local context. }\end{array}$ & $\begin{array}{c}\text {-Sociodemographic } \\
\text { questionnaires } \\
\text {-HFIAS } \\
-48 \text { h reminder } \\
\text {-HAZ }\end{array}$ & $\begin{array}{l}\text { Stunting was } \\
\text { significantly associated } \\
\text { with access to food as } \\
\text { measured by HFIAS for } \\
\text { the sample }(p<0.02) \text {. }\end{array}$ & $\begin{array}{l}\text { The study also showed } \\
\text { that access to food } \\
\text { household income is } \\
\text { positively correlated } \\
\text { with stunting. } \\
35 \% \text { stunting. }\end{array}$ \\
\hline $\begin{array}{c}\text { Modjadji, P. et al. } \\
\text { [50] } \\
2020 \\
\text { South Africa }\end{array}$ & $\begin{array}{c}N_{0}=379 \\
36-59 \text { months } \\
N_{1}=379\end{array}$ & $\begin{array}{c}\text { The sample includes } \\
379 \text { children aged three } \\
\text { to five. } \\
\text { The study was } \\
\text { conducted in the North } \\
\text { West province of South } \\
\text { Africa, more specifically } \\
\text { in the district of Dr } \\
\text { Kenneth Kaunda. }\end{array}$ & $\begin{array}{l}\text { Quantify nutritional } \\
\text { status and dietary } \\
\text { diversity scores and } \\
\text { determine their } \\
\text { association in preschool } \\
\text { children. }\end{array}$ & $\begin{array}{c}\text {-Sociodemographic } \\
\text { questionnaires } \\
\text {-24 h reminder } \\
\text {-HAZ }\end{array}$ & & $\begin{array}{c}\text { No significant } \\
\text { association was observed } \\
\text { between nutritional } \\
\text { indicators and DDS. } \\
29 \% \text { stunting. }\end{array}$ \\
\hline
\end{tabular}




\section{Results}

We identified a total 2398 original articles in six databases. After deletion of the duplicates, 1980 articles were retained. A title-based selection resulted in the exclusion of 1865 articles. Abstracts of the remaining 115 articles were read and reviewed, excluding 75 more articles. After reading the full text of the remaining 40 articles, 21 articles were excluded. Thus, 19 articles meeting the inclusion criteria were selected.

Subsequently, a reverse search was performed on the 19 articles included by searching for the terms in the bibliographic references of the studies to identify original published articles that were not initially selected and which met the integration criteria. Two studies were identified and included, totaling 21 articles for this review.

The representative schema of the research and the number of eligible studies are shown in Figure 1.

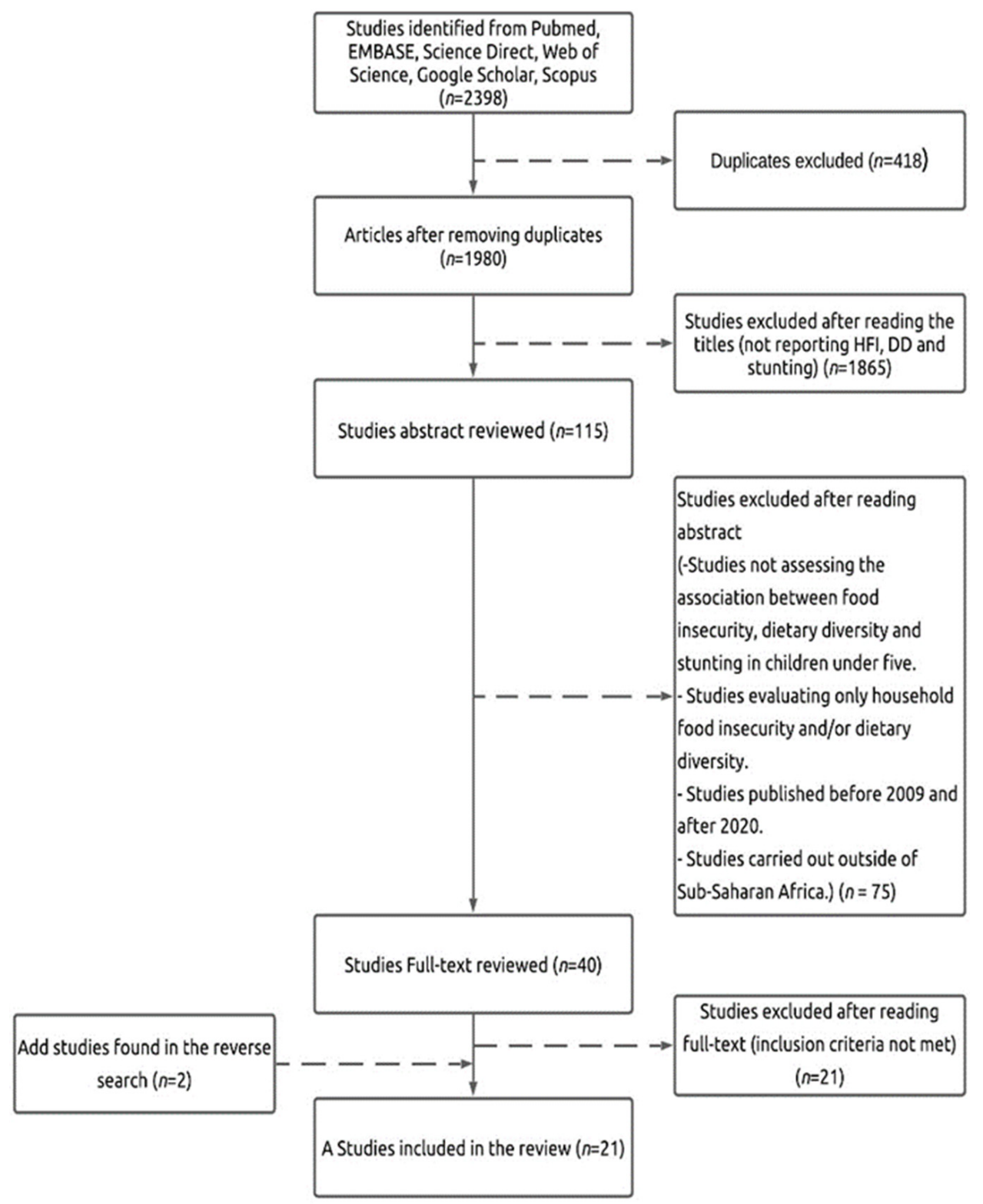

Figure 1. Flowchart for the selection of studies based on the PRISMA 2015 guidelines.

\subsection{Characteristics of Included Studies}

The studies included in this systematic review have been summarized in Table 1 and grouped by sub-region. Thus, thirteen studies were carried out in East Africa, three in 
South Africa, three in West Africa, and one in Central Africa. The sample size ranged from 281 to 6552 households and 251 to 6858 children ranging from 6-59 months. A total of 14 studies reported household food insecurity associated with stunting, 12 studies reported dietary diversity related to stunting, 21 studies reported stunting, 12 studies reported dietary diversity, and 14 studies reported household food insecurity.

During the search, one cohort study was found. This cohort study was conducted in Ethiopia [51]. As our systematic review focuses only on cross-sectional studies, the only cohort study was therefore not included.

\subsection{Evidence from Reviewed Studies}

Table 1 shows the relationship between household food insecurity and stunting and the relationship between dietary diversity and stunting. This table also presents the purposes of studies and the methodology used to evaluate these factors.

Concerning the relationship between household food insecurity and stunting and to have a precise assessment, studies using the HFIAS scale were retained (Table 1). Thus, the studies reviewed had indicated that food insecurity was significantly associated with growth retardation $[31,36,38,39,41-43,46-50]$, with only some studies [38,40,45] finding that this association was not significant. Moreover, the analysis of this association showed that the proportion of children suffering from stunted growth increases with the level of food insecurity in households $[37,39-41,46,47]$ and even more in poor households in food insecurity because food-insecure households generally had lower socioeconomic status than food-secure households [31,39].

In most of the studies reviewed (Table 1), dietary diversity was a factor that significantly increased the risk of stunting in children [33,50], and only two studies [30,32,34-36,38,44,45,48,49] did not demonstrate this association. These results also showed that the many of children with a high dietary diversity were less likely to suffer from stunting.

In virtually all of the studies reviewed $(n=20)$, the prevalence of stunting was reported. Thus, most stunting in children ranged from $23.1 \%$ [32] to $78.86 \%$ [33]. In addition to the factors listed above, the articles reviewed showed that marital status (married) was also a factor associated with stunting $[35,39,42,45]$, but this association was not statistically significant. However, over $90 \%$ of households were married [37,38,40,41,43,44,47-49], and only a study carried out in the North West province of South Africa showed the opposite ( $80 \%$ were single people) [52]. At the same time, some studies said the severity of stunting was higher in the younger age group $[30,45]$.

Moreover, the proportion of children with stunting was higher among mothers with less education (primary or lower) $[37,39,47]$ because a greater proportion of mothers in food-insecure households had no formal education. Some studies showed the proportion of boys suffering from stunting is higher than that of girls [36,46], while others showed the opposite $[38,40]$. Children aged 6 to 59 months from households without year-round access to safe water were more likely to be stunted than those with the ability to access year-round water $[31,41]$.

\section{Discussion}

In our systematic review, household food insecurity was associated with stunting in almost all the articles reviewed for this study. Food insecurity was significantly associated with stunting.

Several similar studies have reported the relationship between household food insecurity and stunting in Canada, Brazil, and China [52-54]. In China, this association was important, and the lack of accessibility to food caused by household food insecurity could be a possible cause of stunting in left-behind children [54]. In Brazil, it was also statistically significant and higher for couples whose heads of household had a low level of education [52]. Other studies in Nepal, Thailand, and Cambodia found no association between household food insecurity and stunting $[52,55,56]$. The proportion of stunted children increased with the level of household food insecurity and even more in poor 
households. These results show the impact of food security and household wealth on the occurrence of stunting.

In this review, dietary diversity was also significantly associated with stunting in almost all of the studies. Thus, the results of our review are similar to those of Cambodian research, which had shown a significant association between dietary diversity in children and growth retardation in children from 12 to 59 months [55]. In addition, our results were similar to another study conducted in forty-two counties in Western China [57]. Another study conducted in India showed that dietary diversity was an important risk factor for growth retardation in infants and young children [58]. However, these results contrast with the conclusions of other studies which found no association between household dietary diversity and stunting in children under 5 in Cambodia [55], Bangladesh [59], and Colombia [60].

In this study, the analysis of our results revealed that in two thirds of articles selected, household food insecurity and dietary diversity were significantly associated with stunting. Thus, we find that these two factors were significant predictors of stunting. These results show the importance of improving household food security and dietary diversity in order to protect the nutritional status of children. However, this does not exclude the need to better understand the roles of other risk factors. Therefore, it is probable that other determinants could affect the influence of dietary diversity on the nutritional status of children.

Thus, parent's educational levels associated with stunting are identical to those of another study conducted in Sub-Saharan Africa [61]. The proportion of children with stunting was higher among mothers with a lower level of education (primary or more down) $[36,38,46]$.

However, stunting in children is also linked to the parent's level of education (mother and father). Likewise, the high level of parental education of parents translates in most cases into higher household income and food security according to a Sub-Saharan Africa study [61]. In Indonesia, a child with a well-educated mother reduces the likelihood of being stunted [62]. In this review, the sex of the child was also linked to stunting. However, the number of boys stunting was higher than of girls [36,46], so girls were less likely to be stunted than boys $[38,40]$. These results are similar to those found in China and Indonesia $[62,63]$.

This study also demonstrated that marital status was associated with growth retardation, but this association was not significant. These results are similar to those of a study in Papua New Guinea [64] which also found a non-significant association between stunting and marital status. Another study carried out in 31 SSA countries had reached the same conclusion [65]. However, an Indian study had shown that the most significant predictor of stunting was the mother's age at marriage [66], and a study carried out in five South Asian countries found that children of formerly married mothers were less likely to be stunted than those of currently married mothers [67].

\section{Recommendations and Strategies to Adopt}

This systematic review will help public health researchers and policy-makers to take action and make policy decisions in the fight to reduce malnutrition in SSA. Thus, the recommendations and strategies to be taken would be, among other things, to improve food security through diversification and availability of food for low-income households. These actions should also concern the education of women and girls, improvement of access to drinking water, modification of access to care through better use of maternal and child health services, and the fight against poverty by improving the socio-economic status of households.

\section{Strengths and Limitations}

We conducted an in-depth search of the existing literature on the association between household food insecurity, dietary diversity, and stunting in SSA. To our knowledge, this 
is the first review to identify the association between these three factors. All the studies included were of high quality.

Several limitations are present in this study. First, qualitative analysis studies were among the exclusion criteria in this review, and only quantitative cross-sectional studies were retained. The inclusion of qualitative studies in systematic reviews allows triangulation of results or offers alternative explanations [29]. Second, we excluded case studies, books, policy briefs, or theses. Finally, this systematic review of transversal design is limited in its capacity to establish a causal relationship between stunting, dietary diversity, and household food insecurity.

\section{Conclusions}

This study showed that household food insecurity and dietary diversity were significantly associated with stunting in Sub-Saharan Africa. However, this review also found that the parent's marital status (married) is a common factor associated with stunting even though this association was not significant. Therefore, there is a need to implement reliable guidelines and strategies to improve household food security and combat child malnutrition. These approaches should include counseling sessions for parents to improve household food security, training sessions for mothers to improve breastfeeding practices and maternal nutrition, and awareness campaigns for good hygiene and sanitation practices. These strategies will make it possible to fight malnutrition effectively and sustainably in the countries of Sub-Saharan Africa.

Supplementary Materials: The following are available online at https://www.mdpi.com/article/ 10.3390/nu13124401/s1, Table S1: Risk of Bias of the Selected Studies by JBI-MAStARI.

Author Contributions: This study was designed by G.G. and J.C.; G.G. carried out the analysis and drafted the manuscript; J.C. was involved in the revision and editing of the manuscript. All authors have read and agreed to the published version of the manuscript.

Funding: This research was funded by the National Natural Science Foundation of China (No. 81472972).

Acknowledgments: We wish to thank the Xiangya School of Public Health.

Conflicts of Interest: The authors declare no conflict of interest.

\section{References}

1. FAO; IFAD; WFP. The State of Food Insecurity in the World 2013; The Multiple Dimensions of Food Security; FAO: Rome, Italy, 2013.

2. Jyoti, D.F.; Frongillo, E.A.; Jones, S.J. Food Insecurity Affects School Children's Academic Performance, Weight Gain, and Social Skills. J. Nutr. 2005, 135, 2831-2839. [CrossRef] [PubMed]

3. Segall-Corrêa, A.M.; Marin-Leon, L.; Helito, H.; Pérez-Escamilla, R.; Santos, L.M.P.; Paes-Sousa, R. Transferência de ren-da e segurança alimentar no Brasil: Análise dos dados nacionais. Nutr. Rev. 2008, 21, 39-51. [CrossRef]

4. Alves, K.P.D.S.; Jaime, P. The national food and nutrition policy and its dialogue with the national food and nutrition security policy. Ciênc. Saúde Coletiva 2014, 19, 4331-4340. [CrossRef] [PubMed]

5. Morais, D.D.C.; Dutra, L.V.; Franceschini, S.D.C.C.; Priore, S.E. Food insecurity and anthropometric, dietary and social indicators in Brazilian studies: A systematic review. Ciênc. Saúde Coletiva 2014, 19, 1475-1488. [CrossRef]

6. Hatløy, A.; Torheim, L.E.; Oshaug, A. Food variety-A good indicator of nutritional adequacy of the diet? A case study from an urban area in Mali, West Africa. Eur. J. Clin. Nutr. 1998, 52, 891-898. [CrossRef] [PubMed]

7. Melgar-Quinonez, H.R.; Zubieta, A.C.; MkNelly, B.; Nteziyaremye, A.; Gerardo, M.F.D.; Dunford, C. Household Food Insecurity and Food Expenditure in Bolivia, Burkina Faso, and the Philippines. J. Nutr. 2006, 136, 1431S-1437S. [CrossRef]

8. Knowles, M.; Rabinowich, J.; de Cuba, S.E.; Cutts, D.B.; Chilton, M. “Do You Wanna Breathe or Eat?": Parent Perspectives on Child Health Consequences of Food Insecurity, Trade-Offs, and Toxic Stress. Matern. Child Health J. 2016, 20, 25-32. [CrossRef] [PubMed]

9. Cook, J.T.; Frank, D.A. Food Security, Poverty, and Human Development in the United States. Ann. N. Y. Acad. Sci. 2008, 1136, 193-209. [CrossRef]

10. Perez-Escamilla, F.; de Toledo Vianna, R.P. Food Insecurity and the Behavioral and Intellectual Development of Children: A Review of the Evidence. J. Appl. Res. Child. 2012, 3, 18. 
11. Shankar, P.; Chung, R.; Frank, D.A. Association of Food Insecurity with Children's Behavioral, Emotional, and Academic Outcomes: A Systematic Review. J. Dev. Behav. Pediatr. 2017, 38, 135-150. [CrossRef]

12. Solagral. The Evolution of the World Food Situation in 1998/99; Tec \& Doc. Lavoisier: Paris, France, 2000.

13. FAO; ECA; AUC. Africa Regional Overview of Food Security and Nutrition 2020: Transforming Food Systems for Affordable Healthy Diets; FAO: Accra, Ghana, 2021.

14. Moursi, M.M.; Arimond, M.; Dewey, K.G.; Treche, S.; Ruel, M.T.; Delpeuch, F. Dietary Diversity Is a Good Predictor of the Micronutrient Density of the Diet of 6- to 23-Month-Old Children in Madagascar. J. Nutr. 2008, 138, 2448-2453. [CrossRef]

15. Arimond, M.; Wiesmann, D.; Becquey, E.; Carriquiry, A.; Daniels, M.C.; Deitchler, M.; Fanou-Fogny, N.; Joseph, M.L.; Kennedy, G.; Martin-Prevel, Y.; et al. Simple Food Group Diversity Indicators Predict Micronutrient Adequacy of Women's Diets in 5 Diverse, Resource-Poor Settings. J. Nutr. 2010, 140, 2059S-2069S. [CrossRef] [PubMed]

16. Labadarios, D.; Mchiza, Z.J.-R.; Steyn, N.P.; Gericke, G.; Maunder, E.M.W.; Davids, Y.D.; Parker, W.-A. Food security in South Africa: A review of national surveys. Bull. World Health Organ. 2011, 89, 891-899. [CrossRef] [PubMed]

17. Rah, J.H.; Akhter, N.; Semba, R.D.; de Pee, S.; Bloem, M.W.; Campbell, A.A.; Moench-Pfanner, R.; Sun, K.; Badham, J.; Kraemer, K. Low dietary diversity is a predictor of child stunting in rural Bangladesh. Eur. J. Clin. Nutr. 2010, 64, 1393-1398. [CrossRef]

18. Branca, F.; Ferrari, M. Impact of Micronutrient Deficiencies on Growth: The Stunting Syndrome. Ann. Nutr. Metab. 2002, 46 (Suppl. 1), 8-17. [CrossRef]

19. WHO. Strengthening Action to Improve Feeding of Infants and Young Children 6-23 Months of Age in Nutrition and Child Health Programmes: Report of Proceedings; WHO: Geneva, Belgium, 2008.

20. Pardutz, A.; Vecsei, L. Should magnesium be given to every migraineur? No. J. Neural Transm. 2012, 119, 581-585. [CrossRef] [PubMed]

21. De Onis, M.; Onyango, A.W. WHO child growth standards. Lancet 2008, 371, 204. [CrossRef]

22. WHO Multicentre Growth Reference Standard Group. WHO Child Growth Standards based on length/height, weight and age. Acta Paediatr. Suppl. 2006, 450, 76-85.

23. FAO. The State of Food Insecurity in the World: High Food Prices and Food Security -Threats and Opportunities; FAO: Rome, Italy, 2008.

24. FAO. Guidelines for Measuring Household and Individual Dietary Diversity; FAO: Rome, Italy, 2011.

25. WFP. Comprehensive Food Security \& Vulnerability Analysis Guidelines; World Food Programme: Rome, Italy, 2009.

26. Swindale, A.; Paula, B. Household Dietary Diversity Score (HDDS) for Measurement of Household Food Access: Indicator Guide (v. 2). In Food and Nutrition Technical Assistance Project; Academy for Educational Development: Washington, DC, USA, 2006.

27. Hoddinott, J.; Yohannes, Y. Dietary Diversity as a Food Security Indicator; Ageconsearch: Minnesota, CO, USA, 2002.

28. Moher, D.; Shamseer, L.; Clarke, M.; Ghersi, D.; Liberati, A.; Petticrew, M.; Shekelle, P.; Stewart, L.A. Preferred reporting items for systematic review and meta-analysis protocols (PRISMA-P) 2015 statement. Syst. Rev. 2015, 4, 1. [CrossRef] [PubMed]

29. Grant, M.J.; Booth, A. A typology of reviews: An analysis of 14 review types and associated methodologies. Health Inf. Libr. J. 2009, 26, 91-108. [CrossRef]

30. Hatløy, A.; Hallund, J.; Diarra, M.M.; Oshaug, A. Food variety, socioeconomic status and nutritional status in urban and rural areas in Koutiala (Mali). Public Health Nutr. 2000, 3, 57-65. [CrossRef]

31. Saaka, M.; Osman, S.M. Does Household Food Insecurity Affect the Nutritional Status of Preschool Children Aged 6-36 Months? Int. J. Popul. Res. 2013, 2013, 1-12. [CrossRef]

32. Sie, A.; Tapsoba, C.; Dah, C.; Ouermi, L.; Zabré, P.; Bärnighausen, T.; Arzika, A.M.; LeBas, E.; Snyder, B.M.; Moe, C.; et al. Dietary diversity and nutritional status among children in rural Burkina Faso. Int. Health 2018, 10, 157-162. [CrossRef]

33. Ekesa, B.N.; Blomme, G.; Garming, H. Dietary Diversity and Nutritional Status of Pre-School Children from Musa-Dependent Households in Gitega (Burundi) and Butembo (DR Congo). Afr. J. Food Agric. Nutr. Dev. 2011, 11, $4896-4911$.

34. Ali, D.; Saha, K.K.; Nguyen, P.H.; Diressie, M.T.; Ruel, M.T.; Menon, P.; Rawat, R. Household Food Insecurity Is Associated with Higher Child Undernutrition in Bangladesh, Ethiopia, and Vietnam, but the Effect Is Not Mediated by Child Dietary Diversity. J. Nutr. 2013, 143, 2015-2021. [CrossRef]

35. Bukania, Z.N.; Mwangi, M.; Karanja, R.M.; Mutisya, R.; Kombe, Y.; Kaduka, L.U.; Johns, T. Food Insecurity and Not Dietary Diversity Is a Predictor of Nutrition Status in Children within Semiarid Agro-Ecological Zones in Eastern Kenya. J. Nutr. Metab. 2014, 2014, 907153. [CrossRef] [PubMed]

36. Motbainor, A.; Worku, A.; Kumie, A. Stunting Is Associated with Food Diversity while Wasting with Food Insecurity among Underfive Children in East and West Gojjam Zones of Amhara Region, Ethiopia. PLoS ONE 2015, 10, e0133542. [CrossRef] [PubMed]

37. Mutisya, M.; Kandala, N.-B.; Ngware, M.W.; Kabiru, C.W. Household food (in)security and nutritional status of urban poor children aged 6 to 23 months in Kenya. BMC Public Health 2015, 15, 1052. [CrossRef] [PubMed]

38. M'Kaibi, F.K.; Steyn, N.P.; Ochola, S.A.; du Plessis, L. The relationship between agricultural biodiversity, dietary diversity, household food security, and stunting of children in rural Kenya. Food Sci. Nutr. 2017, 5, 243-254. [CrossRef]

39. Abdurahman, A.A.; Mirzaei, K.; Dorosty, A.R.; Rahimiforoushani, A.; Kedir, H. Household Food Insecurity May Predict Underweightand Wasting among Children Aged 24-59 Months. Ecol. Food Nutr. 2016, 55, 456-472. [CrossRef] 
40. Mulu, E.; Mengistie, B. Household food insecurity and its association with nutritional status of under five children in Sekela District, Western Ethiopia: A comparative cross-sectional study. BMC Nutr. 2017, 3, 1-9. [CrossRef] [PubMed]

41. Betebo, B.; Ejajo, T.; Alemseged, F.; Massa, D. Household Food Insecurity and Its Association with Nutritional Status of Children 6-59 Months of Age in East Badawacho District, South Ethiopia. J. Environ. Public Health 2017, 2017, 1-17. [CrossRef] [PubMed]

42. Agho, K.E.; Mukabutera, C.; Mukazi, M.; Ntambara, M.; Mbugua, I.; Dowling, M.; Kamara, J.K. Moderate and severe household food insecurity predicts stunting and severe stunting among Rwanda children aged 6-59 months residing in Gicumbi district. Matern. Child Nutr. 2019, 15, e12767. [CrossRef]

43. Shilugu, L.L.; Sunguya, B.F. Stunting in the Context of Plenty: Unprecedented Magnitudes Among Children of Peasant's Households in Bukombe, Tanzania. Front. Nutr. 2019, 6, 168. [CrossRef] [PubMed]

44. Khamis, A.G.; Mwanri, A.W.; Ntwenya, J.E.; Kreppel, K. The influence of dietary diversity on the nutritional status of children between 6 and 23 months of age in Tanzania. BMC Pediatr. 2019, 19, 1-9. [CrossRef] [PubMed]

45. Dinku, A.M.; Mekonnen, T.C.; Adilu, G.S. Child dietary diversity and food (in)security as a potential correlate of child anthropometric indices in the context of urban food system in the cases of north-central Ethiopia. J. Health Popul. Nutr. 2020, 39, 1-11. [CrossRef] [PubMed]

46. Berra, W.G. Household Food Insecurity Predicts Childhood Undernutrition: A Cross-Sectional Study in West Oromia (Ethiopia). J. Environ. Public Health 2020, 2020, 1-9. [CrossRef]

47. Berhane, H.Y.; Jirström, M.; Abdelmenan, S.; Berhane, Y.; Alsanius, B.; Trenholm, J.; Ekström, E.-C. Social Stratification, Diet Diversity and Malnutrition among Preschoolers: A Survey of Addis Ababa, Ethiopia. Nutrients 2020, 12, 712. [CrossRef]

48. Faber, M.; Schwabe, C.; Drimie, S. Dietary diversity in relation to other household food security indicators. Int. J. Food Saf. Nutr. Public Health 2009, 2, 1-15. [CrossRef]

49. Chakona, G.; Shackleton, C.M. Household Food Insecurity along an Agro-Ecological Gradient Influences Children's Nutritional Status in South Africa. Front. Nutr. 2018, 4, 72. [CrossRef]

50. Modjadji, P.; Molokwane, D.; Ukegbu, P.O. Dietary Diversity and Nutritional Status of Preschool Children in North West Province, South Africa: A Cross Sectional Study. Children 2020, 7, 174. [CrossRef]

51. Belayneh, M.; Loha, E.; Lindtjørn, B. Seasonal Variation of Household Food Insecurity and Household Dietary Diversity on Wasting and Stunting among Young Children in A Drought Prone Area in South Ethiopia: A Cohort Study. Ecol. Food Nutr. 2021, 60, 44-69. [CrossRef]

52. Gubert, M.B.; Spaniol, A.M.; Segall-Corrêa, A.M.; Pérez-Escamilla, R. Understanding the double burden of malnutrition in food insecure households in Brazil. Matern. Child Nutr. 2016, 13, e12347. [CrossRef]

53. Pirkle, C.M.; Lucas, M.; Dallaire, R.; Ayotte, P.; Jacobson, J.L.; Jacobson, S.W.; Dewailly, E.; Muckle, G. Food insecurity and nutritional biomarkers in relation to stature in Inuit children from Nunavik. Can. J. Public Health 2014, 105, e233-e238. [CrossRef]

54. Yang, Q.; Yuan, T.; Yang, L.; Zou, J.; Ji, M.; Zhang, Y.; Deng, J.; Lin, Q. Household Food Insecurity, Dietary Diversity, Stunting, and Anaemia among Left-Behind Children in Poor Rural Areas of China. Int. J. Environ. Res. Public Health 2019, 16, 4778. [CrossRef] [PubMed]

55. McDonald, C.M.; McLean, J.; Kroeun, H.; Talukder, A.; Lynd, L.D.; Green, T.J. Household food insecurity and dietary diversity as correlates of maternal and child undernutrition in rural Cambodia. Eur. J. Clin. Nutr. 2014, 69, 242-246. [CrossRef] [PubMed]

56. Osei, A.; Pandey, P.; Spiro, D.; Nielson, J.; Shrestha, R.; Talukder, Z.; Quinn, V.; Haselow, N. Household Food Insecurity and Nutritional Status of Children Aged 6 to 23 Months in Kailali District of Nepal. Food Nutr. Bull. 2010, 31, 483-494. [CrossRef]

57. Darapheak, C.; Takano, T.; Kizuki, M.; Nakamura, K.; Seino, K. Consumption of animal source foods and dietary diversity reduce stunting in children in Cambodia. Int. Arch. Med. 2013, 6, 29. [CrossRef] [PubMed]

58. Corsi, D.J.; Mejía-Guevara, I.; Subramanian, S.V. Risk factors for chronic undernutrition among children in India: Estimating relative importance, population attributable risk and fractions. Soc. Sci. Med. 2016, 157, 165-185. [CrossRef]

59. Saha, K.K.; Frongillo, E.A.; Alam, D.S.; Arifeen, S.E.; Persson, L.Å.; Rasmussen, K.M. Household food security is associated with growth of infants and young children in rural Bangladesh. Public Health Nutr. 2009, 12, 1556-1562. [CrossRef]

60. Hackett, M.; Melgar-Quiñonez, H.; Álvarez, M.C. Household food insecurity associated with stunting and underweight among preschool children in Antioquia, Colombia. Rev. Panam. Salud Públ. 2009, 25, 506-510. [CrossRef]

61. Akombi, B.J.; Agho, K.E.; Hall, J.J.; Wali, N.; Renzaho, A.M.N.; Merom, D. Stunting, Wasting and Underweight in Sub-Saharan Africa: A Systematic Review. Int. J. Environ. Res. Public Health 2017, 14, 863. [CrossRef] [PubMed]

62. Mahmudiono, T.; Nindya, T.S.; Andrias, D.R.; Megatsari, H.; Rosenkranz, R.R. Household Food Insecurity as a Predictor of Stunted Children and Overweight/Obese Mothers (SCOWT) in Urban Indonesia. Nutrients 2018, 10, 535. [CrossRef]

63. Jiang, Y.; Su, X.; Wang, C.; Zhang, L.; Zhang, X.; Wang, L.; Cui, Y. Prevalence and risk factors for stunting and severe stunting among children under three years old in mid-western rural areas of China. Child Care Health Dev. 2014, 41, 45-51. [CrossRef] [PubMed]

64. Pham, B.N.; Silas, V.D.; Okely, A.D.; Pomat, W. Measuring Wasting and Stunting Prevalence Among Children Under 5 Years of Age and Associated Risk Factors in Papua New Guinea: New Evidence from the Comprehensive Health and Epidemiological Surveillance System. Front. Nutr. 2021, 8, 622660. [CrossRef] [PubMed]

65. Amadu, I.; Seidu, A.-A.; Duku, E.; Okyere, J.; Hagan, J.E., Jr.; Hormenu, T.; Ahinkorah, B.O. The Joint Effect of Maternal Marital Status and Type of Household Cooking Fuel on Child Nutritional Status in Sub-Saharan Africa: Analysis of Cross-Sectional Surveys on Children from 31 Countries. Nutrition 2021, 13, 1541. [CrossRef] 
66. Aguayo, V.M.; Nair, R.; Badgaiyan, N.; Krishna, V. Determinants of stunting and poor linear growth in children under 2 years of age in India: An in-depth analysis of Maharashtra's comprehensive nutrition survey. Matern. Child. Nutr. 2016, 12 (Suppl. 1), 121-140. [CrossRef]

67. Wali, N.; Agho, K.E.; Renzaho, A.M.N. Factors Associated with Stunting among Children under 5 Years in Five South Asian Countries (2014-2018): Analysis of Demographic Health Surveys. Nutrition 2020, 12, 3875. [CrossRef] 